\title{
Geomorphological immaturity as a factor conditioning the dynamics of channel processes in Rządza River
}

https://doi.org/10.1515/geo-2020-0209

received July 30, 2019; accepted October 30, 2020

\begin{abstract}
A major part of Poland, classified geographically as Polish Lowland, is covered by a layer of loose or cohesive sediments whose thickness increases toward the north. Numerous authors emphasize the impact of the protrusion of the erosional base level on the course of processes shaping modern river valleys. It has been demonstrated, among other things, that the culmination of the sub-alluvial, cohesive bedrock determines the manner in which the channel zone and the adjacent floodplain are formed, which is associated with the hydrological system of the river. A number (12) of geological documenting holes have been drilled to the bottom of the valley. Also, geological profiles were recorded for 34 natural outcrops. The range of the individual outcrops was determined using a geomorphological analysis based on, among other things, the data from airborne laser scanning. The main objective of the research based on geomorphological criteria was to identify the differences in valley morphology and geological structure as well as the dynamics of currently occurring fluvial processes, along with geological features influencing their development, in particular in the middle course of a river. The research allowed the distinction of three geologically and geomorphologically characteristic sections. This allowed an answer to the question: why is the river in the lowland similar to a mountain stream.
\end{abstract}

\footnotetext{
* Corresponding author: Filip Bujakowski, Department of Water Engineering and Applied Geology, Institute of Environmental Engineering, Warsaw University of Life Sciences, Nowoursynowska 159, 02-776 Warsaw, Poland, e-mail: filip_bujakowski@sggw.pl Tomasz Falkowski: Department of Water Engineering and Applied Geology, Institute of Environmental Engineering, Warsaw University of Life Sciences, Nowoursynowska 159, 02-776 Warsaw, Poland Anna Podlasek: Department of Revitalization and Architecture, Institute of Civil Engineering, Warsaw University of Life Sciences, Nowoursynowska 159, 02-776 Warsaw, Poland
}

Keywords: river valley, alluvium, channel processes, hydrological regime, erosional base level

\section{Introduction}

In the landscape of lowland areas, river valleys are forms with the highest dynamics of morpho- and lithogenetic processes. Their course is closely related to the quality of the natural environment of the catchment area [1]. Starkel [2] stated that processes caused by climatic evolution or changes in valley management are reflected very quickly in the course of erosional and depositional processes. Natural sensitivity to changes taking place in river valleys imposes a need for very precise identification of natural processes occurring in the catchment area. Particular importance is attributed to the interaction between the conditions of water and sediment runoff into the valley, and the spatial diversity of erosional and depositional processes (formulation defined by Lane [3]). Fluvial processes are influenced by both the elements of the natural environment of the whole catchment area (i.e., climatic characteristics $[2,4,5])$ and local phenomena (i.e., the morphodynamics of zones adjacent to the valley [6]), the occurrence of erosion-resistant materials in the bottom of the valley [7-9], tectonic discontinuities [10], or the tectonic activity of zones intersected by the river [11]. The abovementioned factors determine the morphodynamic specificity of a given section of a valley or floodplain. It could be reflected by the shape of the valley or the layout of outcrops of alluvial sediments. In Polish Lowland, the specificity of the geological structure of individual sections of the valleys results from the morphogenetic immaturity of river valleys $[4,12]$ and the complexity of evolutional processes in their bottoms (occurring since the end of the Pleistocene) $[2,4,5,13]$. This is caused by the Pleistocene history of the analyzed area, including the glacial-interglacial rhythm of climate changes [14]. During the formation of 
(1.)

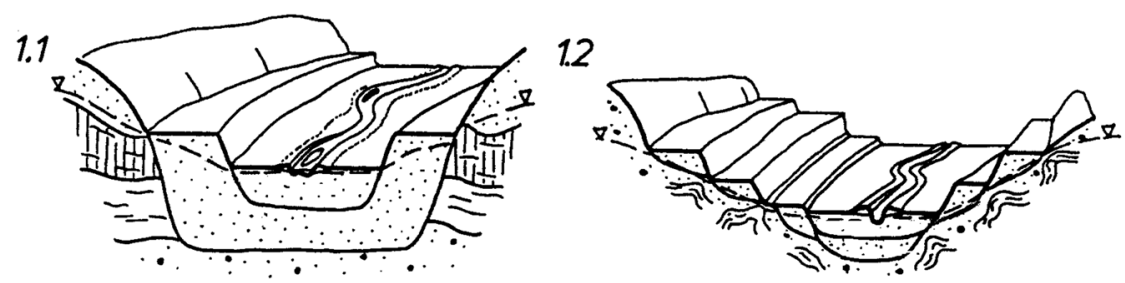

(2)

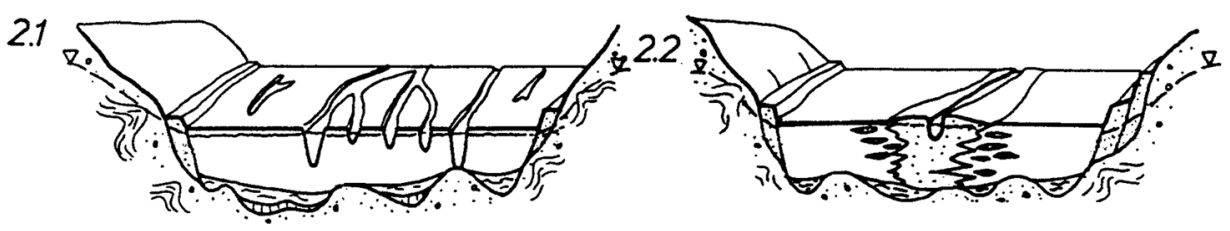

2.3

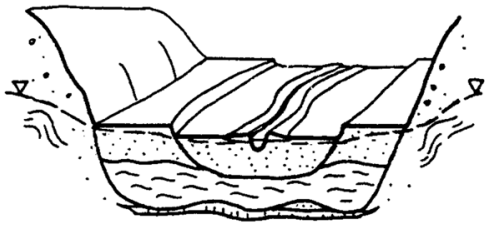

(3.)

3.1



2.4

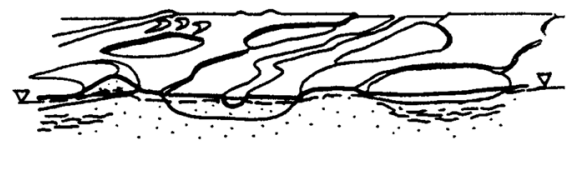

3.2


a.


c. $\therefore \circ$
d. $\approx$
e. 响血正
f. ल
g. -
h. a

Figure 1: Morphogenetic diversity of sections of river valleys in the Polish Lowland (after [12]). 1- Erosion-accumulation section, 2 - post-lake section, 3 - section of the river where the bedrock protrusion is exposed, a - organic soils, b-sands, c-gravels, $\mathrm{d}$ - cohesive soils, $\mathrm{e}$ - till, $\mathrm{f}$ - glacitectonic deformations, $\mathrm{g}$ - groundwater level, $\mathrm{h}$ - spring.

the surface runoff network, rivers often adapted glacigenic depressions to the sections of their valleys (e.g., lake basins or thermokarstic depressions), eroding only sections placed between them. The fact that lower sections of large river valleys often have the youngest relief, contrary to the classical concepts of morphological development according to [15], is another source of their morphogenetic specificity in Polish Lowland (and numerous other smaller forms). These zones were the last to be released from the cover of a "retreating" ice sheet (e.g., Vistula, Oder, and many of their tributaries). The hydrological regime is also an important factor affecting the development of river valleys. The conditions of supplying and draining a watercourse by a groundwater stream constitute an important aspect.

Research conducted in many river valleys in Polish Lowland $[12,16,17]$ allowed the distinction of several types of their morphogenetic sections, differing in geological structure, and for which it is possible to define a specific type of hydrogeological, geological, and engineering conditions (e.g., the nature of alluvial aquifers supplying the riverbed with subsurface runoff; Figure 1) [18]. 
In addition to erosional-accumulational sections (see 1 in Figure 1), in which a deep erosional base level is filled with a series of alluvia of the channel facies, forming a clearly visible terrace system (river terraces and kame terraces; see 1.2 in Figure 1), there are distinguishable polygenic forms, where glacigenic or thermokarstic depressions have been adapted as valley sections. Their size and the supply of clastic material depending on its hydrological characteristics determined the extent to which the original genesis of a depression is readable in morphology and geological structure. Figure 1 shows sections representing different phases and intensity of processes of adaptation to valley formation, including wide peat forms functioning under the conditions of debris deficit (see 2.1 in Figure 1), valleys in which the river was able to build an alluvial dike in a glacial/thermokarstic depression (see 2.2 in Figure 1), and forms in which changes in the hydrological regime resulting from climatic evolution have led to the burial of lacustrine sediments under contemporary channel alluvia (see 2.3 in Figure 1). A slightly different type is represented by rivers currently operating in outwash plain areas (see 2.4 in Figure 1). They also use small thaw depressions in valleys, but the main factor conditioning their morphodynamics involves very low gradients as well as the presence of dune forms limiting the lateral erosion and the inflow of water into the valley $[16,17]$. Polygenic segments are connected by sections formed mainly by erosion. Within their bottoms, sediments resistant to flowing water are often revealed (especially during high water levels - see 3.1 and 3.2 in Figure 1). A typical example of such a form is a section of the Vistula River in Warsaw [19]. The list of types of morphogenetic sections can be extended, because the fluvial environment is characterized by a great diversity. From the point of view of engineering practice, an important feature of the fluvial environment in Polish Lowland (and certainly in other areas of the postglacial terrain) is that individual sections can be identified based on morphogenetic criteria.

The Rządza River valley in the eastern part of Mazovian lowland was selected as the research area. This river was chosen because of its hydrological regime and the shape of its valley. One part of valley could be considered as similar to a mountain stream, in spite of the river being located in the lowland [20]. The Rządza River used to be a left-bank tributary of the Narew River. Since 1963, when the dam on the Narew River in Dębe was put into service, the Rządza River has been flowing into a reservoir created this way called the Zegrze Lake. The length of the river is approximately $66 \mathrm{~km}$, and the size of the catchment area is $475.9 \mathrm{~km}^{2}$ [20].

\section{Geological background}

The source zone of Rządza is located within the morainic Kałuszyn upland. The creation of this form is related to the dissipation of ice sheet from the Warta glaciation (MIS 6) [21]. The surface of the Kałuszyn Upland is made of glacial tills of the Warta Glaciation covered by fluvioglacial sediments (mainly sands). The spring zone of the valley is located within a depression of approximately $3.2 \mathrm{~km}^{2}$ filled with organic sediments. The depression is delimited by layers made of glacial till and fluvioglacial sands. Numerous dunes occur in the top of sandy surfaces. In a section downstream of Wola Polska (Figures 2 and 3), fluvial erosion has uncovered glacial till in many parts of the uphill slope. The thickness of the Warta morainic sediments in the vicinity of the valley equals $8-10 \mathrm{~m}$ [22]. These sediments lie directly on the clayey deposits of the Odra glaciation. From Rakówiec, going down the river, the erosional base level is formed in morainic sediments of the Odra glaciation. In the area of Mlęcin and Wola Polska, the influence of the Dobre Structure [23] uplifted by glacial tectonics is visible in the development and the course of the valley. This structure, documented during the preparation of the Minsk Mazowiecki sheet of the general map of Poland, consists of highly disturbed Pliocene clays, which locally reveal themselves in the form of "displaced rock blocks" and "ice drift" on the surface. According to [23], its upheaval probably led to the displacement of the Rządza valley toward the southwestern direction from Wiśniewo to Osęczyzna. Considering the issue of the influence of neotectonic movements in Mazovia on the shape of the river network, it can be stated with certainty that the presence of the Dobre Structure has an impact on the shape of the Rządza valley. Downstream of Osęczyzna, the valley turns toward the west and takes an almost latitudinal course (Figure 2). This is related to the occurrence of significant land denivelations resulting from the presence of dune fields in the region of Stanisławów. It can be also associated with the impossibility of free meandering of the river due to the specific construction of the erosional base level. It can also be related to the adaptation of depressions to flow paths [23]. Downstream of the Ołdakowizna village, in the area of Turze, the valley extends in the vicinity of the sandy surfaces of fluvioglacial sedimentation. According to the Tłuszcz sheet of the geological map of Poland [24], sandy deposits form the surface of wide and flat alluvial fans. In here, differences in elevation are decreasing and the width of the Rządza valley is expanding considerably. Its boundaries in this zone are difficult to determine. Sediments of both the Odra and 




Figure 2: Location of the study area based on a geological map of Poland 1: 500000 (www.pgi.gov.pl). 3 - Fluvial muds, 5 - eolian sands, locally in the dunes, 11 - fluvial sands, 24 - outwash sands and gravels, 28 - tills, weathered tills.

Warta glaciations descend to an elevation below the bottom of the valley (100 $\mathrm{m}$ above sea level) and no longer actively participate in shaping the course of contemporary channel processes.

The main objective of research based on geomorphological criteria was to identify differences in valley morphology and geological structure as well as the dynamics of currently occurring fluvial processes, along with geological features influencing their development. The presented research has the nature of a case study for the Rządza River valley in central Poland.

\section{Materials and methods}

\subsection{Archive materials}

The analysis of historical data included topographic maps in the scale of 1:10,000 (24 sheets along the valley), geological and hydrogeological maps in the scale of 1:50,000 (6 sheets along the valley) and the numerical terrain model (NMT) prepared on the basis of airborne laser scanning. The data were obtained from the resources of Polish Geological Institute - National Research Institute (geological and hydrogeological maps) and from the Geodetic and Cartographic Documentation Centre (NMT). The data were developed in a digital form, originating from the ISOK project which addresses a need for the delimitation of flood-prone areas in river valleys in Poland. Its acquisition took place after the 2010 flood, which affected numerous river valleys in Poland, e.g., the Vistula River valley $[25,26]$. We purchased the data as ASCII (XYZ) files with a vertical error of $0.1 \mathrm{~m}$ and 147 sheets of a map in the scale of 1:5,000.

A database was prepared by using the ArcGIS ver. 10.5 (ArcGIS $^{\circledR}$, Esri) geographic information system (GIS). The software was installed on a GIS workstation computer with an E5-1650 v4@ $3.60 \mathrm{GHz}$ Intel $^{\circledR}$ Xeon $^{\circledR}$ CPU to enable the transformation of the ASCII (XYZ) files into a set of data points in a space (a point cloud). The data were subsequently saved as numerous SHAPE files. Afterward, the SHAPE files were transformed into raster files. Next the symbology of all the raster files was unified (attributes merged) via the creation of a mosaic. In the 
next step, the mosaic was transformed into a final raster data set and it was saved in the form of a single SHAPE file. Additionally, the pyramids feature was built for the SHAPE file. The pyramids accelerate the drawing of maps, cross-sections, and the reading of elevation from a SHAPE file. Final elevation data were prepared in order to make it legible in two compositions: hypsometric color palette and shades of gray (hillshade). The individual thematic layers and the entire base structure were based on the PUWG 1992 coordinate system. Separate thematic layers (.shp) were created for individual categories of studies and observations, and the data contained therein were formulated in a way which made it possible to use it directly in the hydrogeological modeling environment (Visual Modflow library) in the next step of research.

\subsection{Identification of the lithology of sediments exposed in the channel zone}

The initial research was based in particular on an analysis of historical cartographic materials supplemented with the latest remote sensing data. Subsequently, local inspections were carried out along the entire length of the watercourse, and detailed geological and geomorphological mapping of the valley were performed from the Wola Polska village to Turze (Figures 2 and 3). The field inspections carried out from March to May 2019 covered the entire river valley, from its spring located north-east of Mińsk Mazowiecki (Figure 2) to the estuary in the area of Stare Załubice.

The work involved the implementation of photo documentation of the channel area and the adjacent terraces as well as the drilling of 12 shallow boreholes documenting the geological structure of the river channel substratum. On this basis, certain sections were selected, which in the next step underwent a more detailed analysis. Generally, it consisted of geological mapping of the bottom, and the profile of the channel was subsequently uncovered every 100-200 $\mathrm{m}$ along the course of the river, in characteristic points where the outcrops of the subsoil were exposed, or where there were clearly visible sediments with macroscopically distinct features. In a zone between Wola Polska and Turze, in places where the erosional base level was covered by sandy alluvial sediments, 12 boreholes were drilled to a depth of $6 \mathrm{~m}$ or to the top of cohesive soils. In this zone, geological profiles were also recorded in 34 natural outcrops. The collected soil samples were then subjected to grain size analyses.

Additionally, in order to confirm the shape of the boundary between the Pleistocene and contemporary
Holocene alluvia, dating was performed for a sample of wood collected from the top of the glacial till of the erosional base level. The dating was carried out using a radiocarbon method in the Poznań Radiocarbon Laboratory. Locations of all documenting points were established using the GPS/global navigation satellite systems (GNSS) equipment (Garmin Etrex 30). Moreover, photographs taken as part of photographic documentation performed in this study had their location attributes in the form of $X$ and $Y$ labels in the WGS 84 system, which were then transformed to the PUWG 1992 system in the developed GIS database.

\section{Results}

This type of research is most often conducted in the valleys of large rivers, and it is related to flood safety and catchment area management $[19,25]$. In this case, the results were used to assess the formation rates in the valley area of a river with the features of a mountain stream.

The conducted research was based in particular on the identification of the geological structure of the Rządza River bed by using geological mapping. The material from documented, characteristic outcrops of layers was then subjected to macroscopic and grain size analyses. On this basis, four sections of the valley were distinguished (A, B, C, D; Figure 3, Table 1), which were characterized by different geological structure of the riverbed subsoil. In the next part of the research, an attempt was made to trace the borders of these zones using a geomorphological analysis based on remote-sensing materials.

Distinctive features of these sections include in particular: the shape of the valley, the development of terrace surfaces, the geological structure of the channel and the floodplain, and the supply of clastic.

\subsection{The "spring" section}

The source zone of the river is located between Chrościce and Marianka at an elevation of about $181 \mathrm{~m}$ a.s.l. According to a division based on the Uniform Bodies of Surface Water, the source of the Rządza River is located between the Żebrówka and Kluki villages, at an elevation of about $194 \mathrm{~m}$ a.s.l. Both cases have to do with concentrated, discrete outflows of groundwater, which in the context of the morphology of both zones may be associated with hydrological drought, which prevailed during the research. 


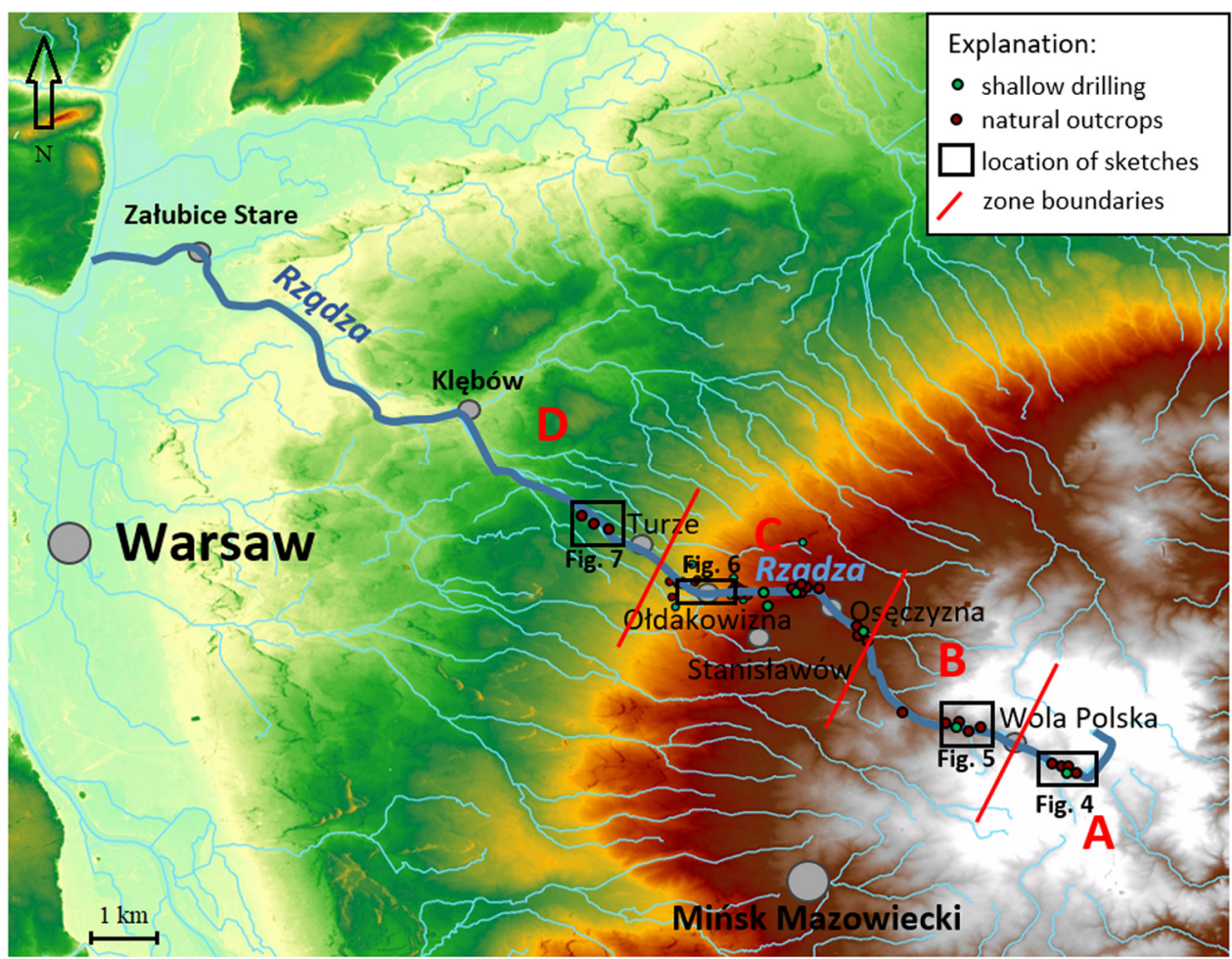

Figure 3: The research area with boundaries of morphogenetically characteristic sections presented as the DEM image.

The first section, approximately $8.5 \mathrm{~km}$ long, is a narrow stream canalized in many parts of the river. The river ends with a dam reservoir in the vicinity of Wola Polska. In the valley axis, the distance is $7.8 \mathrm{~km}$, which indicates a tortuosity of 1.09 . The valley cuts through the uplands with elevations reaching up to $199 \mathrm{~m}$ a.s.l. The bottom of the channel in the vicinity of the highest point has an elevation of $171 \mathrm{~m}$ a.s.l., resulting in the maximum difference in elevation amounting to $28 \mathrm{~m}$. The slopes of the valley are relatively smooth without terrace surfaces. The longitudinal gradient of the channel in this section is between 0.21 and $0.42 \%$ in the vicinity of Wiśniew.

In a section located about $15 \mathrm{~km}$ away from the spring, the valley is formed as a "V-shaped" gutter with a trough located in the axial part of the valley. The slopes of the valley are formed in the glacial till of the Warta glaciation, on which lie the fluvioglacial deposits. In many places, especially in the lower parts of the slopes, slopewash layers of sandy-clayey sediments were found. These surfaces are clearly inclined toward the river channel, as can be seen in the digital elevation model (DEM) image (Figure 4).

\subsection{Section of the river where the bedrock protrusion is exposed (B and C)}

The bottom of the riverbed downstream of the weir has an elevation of $164.1 \mathrm{~m}$ a.s.l., and the damming level is $2.3 \mathrm{~m}$. The section of the river where the bedrock protrusion is exposed is $22.5 \mathrm{~km}$ long ( $17.4 \mathrm{~km}$ in the axis of the valley).

Table 1: Selected geomorphological parameters of the Rządza River

\begin{tabular}{lllll}
\hline & $\begin{array}{l}\text { Zone 1 } \\
\text { (Spring zone) }\end{array}$ & $\begin{array}{l}\text { Zone 2 (Clay of Warta glaciation } \\
\text { protrusion expose) }\end{array}$ & $\begin{array}{l}\text { Zone 3 (Clay of Odra glaciation } \\
\text { protrusion expose) }\end{array}$ & $\begin{array}{l}\text { Zone 4 } \\
\text { (Alluvial zone) }\end{array}$ \\
\hline Valley width (m) & $0-80$ & $80-360$ & $50-140$ & $160-2,420$ \\
Longitudinal slope (\%) & $0.21-0.42$ & $0.21-0.33$ & $0.16-0.52$ & $0.08-0.23$ \\
$\begin{array}{l}\text { Slope height (up } \\
\text { to) }(\mathrm{m})\end{array}$ & 3.2 & 7.7 & 6.2 & 2.4 \\
$\begin{array}{l}\text { Riverbed tortuosity (-) } \\
\text { River }\end{array}$ & 1.09 & 1.32 & 1.51 & 1.13 \\
\hline
\end{tabular}




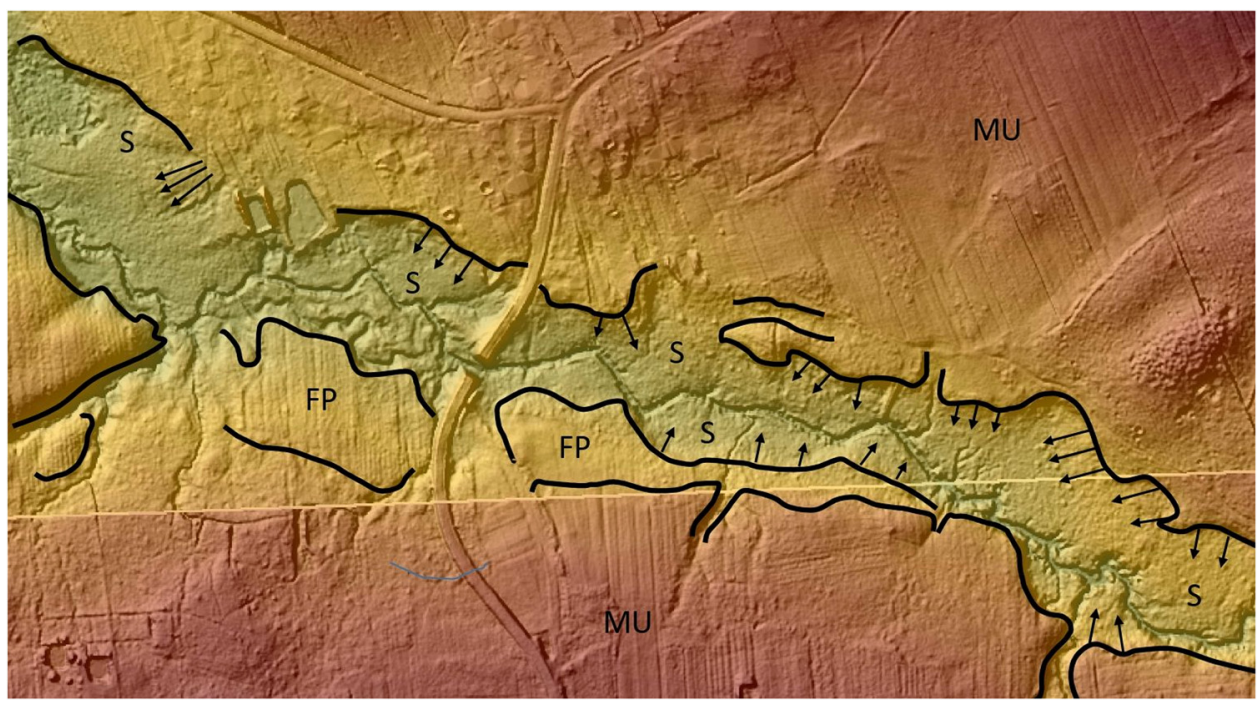

Figure 4: The upper section of the Rządza River presented as the DEM image: FP - fluvioglcial plain, S - slope, MU - moraine upland.

The tortuosity of this section is 1.4. The average longitudinal slope of the riverbed ranges from $0.16 \%$ in the vicinity of Turze to $0.52 \%$ in the vicinity of Osęczyzna and Ołdakowizna. Starting from the reservoir located near Wola Polska, the characteristics of the valley are clearly changing (Figure 5).

The valley is much wider (locally up to $360 \mathrm{~m}$, Table 1), with a clear floodplain developed inside it. Deep-seated erosion caused the cutting of the level of brown till (Warta glaciation), reaching the underlying fluvioglacial sands which are uncovered in the river channel. These sands do not form a continuous level and their floor is arranged in accordance with the course of the river. In zones where the erosion of the river did not reach their floor, the width of the valley is the largest. In zones where both tills are not separated by a sandy layer (the valley cuts into a series of glacial tills of both glaciations), the width of the valley decreases even down to $50 \mathrm{~m}$, and its slopes become steeper (Figure 6). This is second part of a river with the features of a mountain stream.

Flood waters spill onto the floodplain only during the largest overbank flows. The surface of the upland in the vicinity of the valley is covered by aeolian sands. Because the erosion of the river has been stabilized along sections of the Odra glaciation tills, these sands are the main source of supply for contemporary alluvial sedimentation. In this zone, dune fields constituting an area supplying the valley with clastic material can be seen. The age of the border between the Pleistocene and contemporary deposits has a significant impact on the relatively high dynamics of land-shaping processes in this section. The dating of a fragment of the trunk of a tree found in
Ołdakowizna (Figures 2 and 3 ) at the border of the till and the above-lying alluvial channel sediments showed an age of only about 600 years.

Downstream of Ołdakowizna, outcrops of the erosional base level are becoming increasingly rare. The river flowing upstream from Kałuszyn begins to form its valley in the sands of older glaciations of the Wołomin

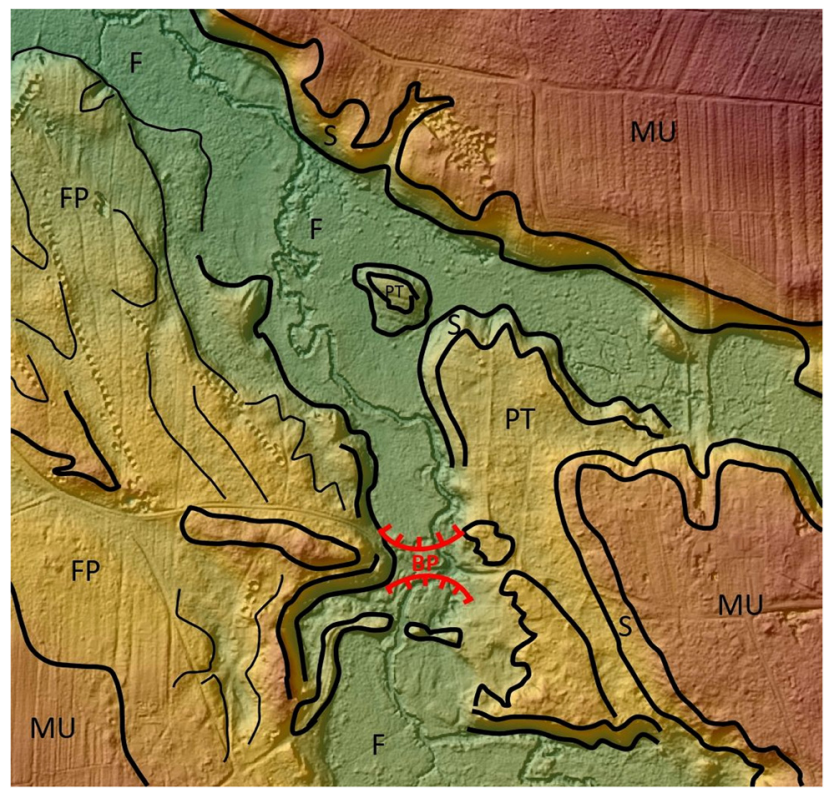

Figure 5: Section of the Rządza River where the bedrock protrusion is exposed, formed in fluvioglacial sands and loams of the Warta glaciation, and presented as the DEM image. FP - Fluvioglcial plain, $\mathrm{S}$ - slope, MU - moraine upland, F - floodplain, PT - Pleistocene terrace, $\mathrm{BP}-$ bedrock protrusion. 


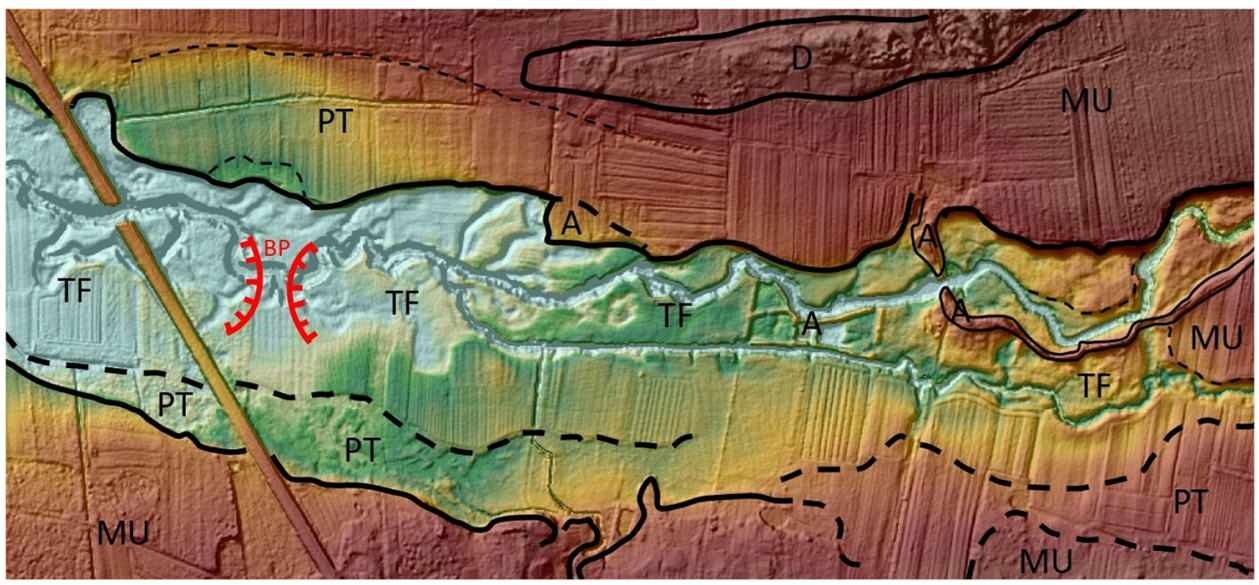

Figure 6: Section of the Rządza River where the bedrock protrusion is exposed, formed in fluvioglacial sands and loams of the Odra glaciation, and presented as the DEM image. TF - Transformed floodplain, MU - moraine upland, PT - Pleistocene terrace, BP - bedrock protrusion, D-dune, A - anthropogenic structure.

Plain. Downstream of Turze, the outcrops of till are no longer present in the river channel. In this zone, a noticeable decrease was observed in the cumulative flow rate, which resulted from the small gradient of the groundwater table that occurs within the Wołomin Plain. This longest distinct section of the valley has been defined as "alluvial."

\subsection{The alluvial section (outwash plain)}

Unlike the sections described above, the alluvial section has clear traces of river engineering (Figure 7).

The bottom of the riverbed downstream of the weir in Turze is situated at $188.8 \mathrm{~m}$ a.s.l. The damming level of the structure is $1.8 \mathrm{~m}$, but the weir is generally lowered and the flow proceeds freely without damming. The alluvial section with a length of $39.9 \mathrm{~km}(35.4 \mathrm{~km}$ in the axis of the valley) ends with an estuary in the Zegrzyński reservoir (the elevation of the mouth is about $77 \mathrm{~m}$ a.s.l.). Due to numerous river engineering operations performed in the lower section, its tortuosity is insignificant and equals about 1.13 .

In a section located downstream of Turze, the longitudinal gradient of the channel level ranges between $0.23 \%$ in the meadows downstream of Turza and $0.08 \%$ in the area of Klębów and Stare Załubice, and the shape of the valley becomes typically alluvial. In the area of Klębów and further downstream, it forms a wide marshy valley. The shape and nature of the riverbed in this zone clearly indicate anthropogenic transformation. As reported by [27], the river channel was subjected to considerable engineering in this zone. The river carries its waters through a system of trenches and culverts. In the estuary, along a section of about $8 \mathrm{~km}$, the riverbed is embanked.

The valley is very wide, sometimes exceeding $1 \mathrm{~km}$, and its boundaries are very blurred. Originally, this area consisted of peatlands and wetlands with a shallow riverbed having a clear tendency to create extensive meanders and oxbows. Currently, as a result of land amelioration, the course of the river has changed. For the most part of its length, it flows in an artificial channel. The area is drained by a significant number of ditches and culverts perpendicular and parallel to the channel. Small

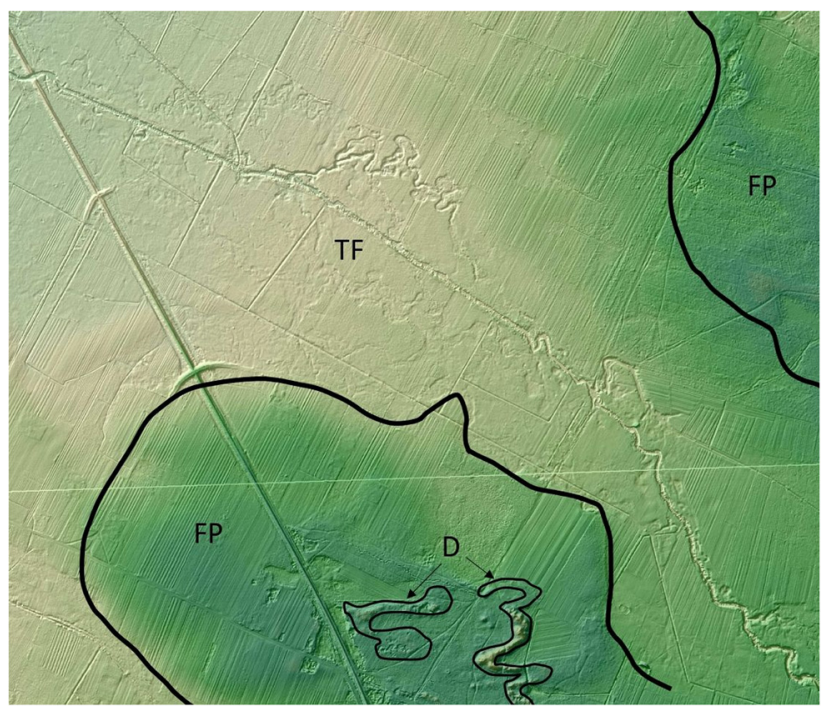

Figure 7: Alluvial section (outwash plain) below the section where the bedrock protrusion is exposed and presented as a DEM image. FP - Fluvioglacial plain, D - dune, TF - transformed floodplain. 
differences in the elevation of the Wołomin Plain make the borders of the valley difficult to determine in the elevation model. The maximum flow velocities are still two times lower than those recorded in the section of the river where the bedrock protrusion is exposed (Table 2). In the vicinity of Klębów, identified flat "shelves" are located up to $1.5 \mathrm{~m}$ above the contemporary floodplain. They can be a part of residues of higher levels of fluvioglacial sedimentation. The longitudinal gradient of the valley in the alluvial section rarely exceeds $0.1 \%$ and the nature of the river becomes typical of a lowland.

\section{Discussion}

The geological structure of areas cut by the valley is an important factor conditioning the course of modern fluvial processes. First of all, the erosion resistance of soil in various tectonic structures affects the shape of the river network $[10,28]$. Soil outcrops with higher resistance also determine the shape of the riverbed and the type of riverbed processes [29,30]. Most often, however, the diversity of resistance of soils being cut into determines the morphodynamics of young forms [31]. In the case of lowland river valleys, which should be characterized by geomorphological maturity, the course of modern processes should be conditioned primarily by the hydrological regime $[2,4,32]$ The valleys of such rivers usually contain a large volume of alluvial formations in which the river can freely evolve [33]. The geomorphological nature of landscape in Polish Lowland does not result from advanced denudation processes but from the complexity of its primarily glacial morphogenesis [34,35]. Having been active since the disappearance of ice sheets, in the case of central Poland only since about $250 \mathrm{ka}$ BP (MIS 8) to $215 \mathrm{ka}$ BP (MIS 6), the rivers have not managed to develop mature valley forms. Their current morphology and geological structure are closely related to the zonation of the postglacial area [36]. The Rządza valley constitutes an example of such a form.

Table 2: Hydrological parameters of the Rządza River

\begin{tabular}{llll}
\hline Location & $\boldsymbol{Q}\left[\mathrm{m}^{3} / \mathrm{s}\right]$ & $\boldsymbol{V}_{\max }[\mathrm{m} / \mathrm{s}]$ & $\boldsymbol{F}\left[\mathrm{m}^{2}\right]$ \\
\hline Wola Polska (Rządza 1) & 0.03 & 0.30 & 0.17 \\
Osęczyzna (Rakówiec) & 0.18 & 0.53 & 0.49 \\
Ołdakowizna (Rządza veir) & 0.16 & 0.70 & 0.22 \\
Turze (Laskowizna) & 0.21 & 0.28 & 0.94 \\
\hline
\end{tabular}

In spite of its small length (not exceeding $100 \mathrm{~km}$ ), the Rządza River flows through four clearly distinct sections (A, B, C, D) resulting from the geological structure. In all of these zones, the development of the valley and the processes occurring in it seem to be strongly conditioned by the erosion resistance of the sediments occurring therein.

Deep erosion prevails in the first zone, which can be described as similar to a mountain stream. Due to the significant longitudinal gradient of the channel, the river cuts in a V-shaped manner into clayey soils in order to reduce the gradient in a lengthwise direction. The shape (slope locally exceeding 5\%) and lithology (cohesive deposits) of the valley slopes show that the surface runoff is of great importance in supplying the river. As can be assumed, drainage is limited in this section, because the channel bottom is formed in morainic sediments. The contact of surface water with groundwater is therefore significantly limited in here $[37,38]$. In the discussed section, no accumulation of Pleistocene terrace level was noted. Locally, in zones where the valley is expanding, accumulation of organic deposits was pronounced. However, fluvial erosion is definitely dominant in this section.

In the groundbreaking section further downstream, the main factor conditioning modern morphodynamics involves the diversity of resistance to the washing out of glacial sediments which are being cut through. In the upper part of the zone, Rządza cuts through a layer of highly sandy brown till, whose age is defined as the Warta glaciation. The cutting of the river into the top of the layer has resulted in the formation of a flat bottom of the valley covered by a series of sandy alluvia with small thickness. The slopes of the valley also constituted a preservation zone of this layer, with traces of slope processes. Paradoxically, the importance of lateral erosion is increasing within the groundbreaking section. Within the floodplain, traces of riverbed migration and avulsion are clear. Cutting through the brown till layer will stabilize the bottom level of the valley, because the gray clay lying below this layer is much more resistant to being washed out (Odra glaciation - MIS 8). Such differentiation of strength parameters of both glacial series is their consistently appearing feature in central Poland [39]. In areas where their outcrops occur in a trough, its shape can be considered to be well established. The nature of the floodplain changes in particular within the zone of their outcrops. Traces of meandering have been blurred, although even the highest water level does not reach the floodplain. The reason for this is probably the morphogenic efficiency of ice jam flooding. The formation of ice jams is documented in the vicinity of the outcrops of tills 
which are hard to be washed out, covered by residual rubble in the bed. For example, in the vicinity of the Ołdakowizna village, near an entirely sub-alluvial protrusion, traces of dynamic flows can be found on the floodplain. Downstream of Ołdakowizna, the outcrops of cohesive sediments are hidden deeper and deeper under the sandy sediments filling flat alluvial fans that reach further into the plains formed by glacial sedimentation (sandurs?). The low longitudinal gradients of the valley and the riverbeds are the reason for the low morphogenic activity of the studied river zone.

In the hydrology of the Rządza River, a distinct tripartite system is also observed. The first section, with the exception of the flat spring zone, with the prevalence of areas of surface water stagnation and deposition of organic sediments of small thickness, is characterized by surface runoff supply (slopes of up to $5 \%$ and cohesive soils in the slopes). The riverbed cutting into cohesive morainic sediments is isolated and has a transitional nature $[17,37]$. Surface runoff occurs mainly along the slopes of an upland plateau, as evidenced by slopewash covers. Abundant water outflow at the edge of the plateau from sandy layers within the till locally forms springs, from which water flows into the riverbed in a more or less concentrated manner. Referring to the classification of river sections in Polish Lowland cited in the introduction [17], this fragment of the Rządza valley corresponds to type 3.2 (Figure 1).

In the middle section, drainage of the river occurs in two ways. In the elevation zone of the erosional base level, groundwater is drained by Holocene sediments that also form the floodplains and then drain water from the border of sandy and low-permeable sediments directly into the riverbed. On the other hand, in places where the erosional base is lowered, the river supply is dominated by underground outflow. River waters in this zone have direct contact with the groundwater of the first aquifer.

In the lower section, downstream of the Oldakowizna village, there are local trends of changes in the hydrodynamic nature of the river from drainage to infiltration, especially during floods. Such changes are generally favored by a low level of the groundwater table in the area of glacial accumulation plains. This phenomenon is related to a climate change $[1,40]$, which is also observed in Central Europe [41]. This trend is intensified by the impact of flood embankments in the estuarian section. In this zone, clear supply of underground structures with river waters can be expected during a flood episode.

The presented diversity of the functioning of the Rządza River along its individual sections is a typical feature of river valleys in Polish Lowland [42]. The importance of the origin of the area in the shaping of the geological structure of fluvial forms and its modern morphodynamics indicates a potential for geomorphological studies documenting the natural conditions of development or protection of river valleys [43,44]. Their inclusion in research plans can increase the efficiency of work and the reliability of the results obtained.

\section{Conclusions}

The presented research allowed the distinction of valley sections differing in several aspects: the shape of the valley, the nature of terrace surfaces, the geological structure of the valley substratum and its slopes, and the supply of clastic material. The conducted research allowed the formulation of the following specific conclusions:

- Presented studies have allowed the separation in the following sections of the valley: a "spring" section, two sections where the bedrock protrusion is exposed (differing from each other in terms of geological structure and morphology) and a lower alluvial section.

- Differences in the lithology of glacial tills occurring in the valley substratum are visible in the morphology of its individual sections. The dissipation of gray till (Odra glaciation) downstream of the Osęczyzna village (and possibly climatic evolution) caused a change in the morphodynamic nature of the river, which transformed the floodplain during ice blockage of river flows, blurring the traces of meandering. Stabilization of fluvial erosion has also been recorded in the morphology of the deeply cut (up to $6.2 \mathrm{~m}$ ) riverbed of Rządza near Ołdakowizna.

- The ranges of the individual zones can be determined based on their shape using remote-sensing materials. In this respect, the LIDAR data presented in a colorscale composition obtained using the hillshade function seem to be particularly useful.

- Morphodynamic analysis based on geomorphological criteria can be helpful when determining the sections of the valley with a specific hydrological regime.

- The features of the mountain stream, visible in the central section (zone 3) of the Rządza River valley, are the result of the occurrence of the Odra glaciation clay outcrops, which are highly resistant to erosion. Since the melting of the glacier, the river has not managed to properly develop its erosive base. Radiocarbon dating of sediments showed that the floodplain in the middle section did not begin to form until about 600 years ago. 
Acknowledgments: The presented research was carried out as a part of the project entitled: "The impact of geological structure on the conditions of supplying small rivers with a system characteristic of the eastern part of Mazovia by underground inflow," financed from the own funds of the Warsaw University of Life Sciences.

Funding: This research was partially funded by the National Science Centre, Poland, under a grant number 2017/25/N/ST10/00909.

\section{References}

[1] Vandenberghe J. The relation between climate and river processes, landforms and deposits during the quaternary. Quaternary Int. 2002;91:17-23.

[2] Starkel L. The reflection of hydrologic changes in fluvial environment of the temperate zone during the last 15,000 years. W: Background to paleohydrology (red. J. Gregory). Chichester: J. Wiley; 1983. p. 213-34.

[3] Lane EW. The importance of fluvial morphology in hydraulic engineering. Am Soc Civ Eng Proc. 1955;81(745):17.

[4] Falkowski E. Variability of channel processes of lowland rivers in Poland and changes of the valley floors during the holocene. Biul Geologiczny. 1975;19:45-78.

[5] Kozarski S, Rotnicki K. Valley floors and changes of river channel patterns in the north polish plain during the late wurm and holocene. Quaest Geographicae. 1977;4:51-93.

[6] Mather AE, Stokes M, Whitfield E. River terraces and alluvial fans: The case for an integrated Quaternary fluvial archive. Quaternary Sci Rev. 2017;166:74-90. doi: 10.1016/ j.quascirev.2016.09.022.

[7] Spotila JA, Moskey K,A, Prince PS. Geologic controls on bedrock channel width in large, slowly eroding catchments: Case study of the new river in eastern North America. Geomorphology. 2015;230:51-63. doi: 10.1016/ j.geomorph.2014.11.004.

[8] Konsoer KM, Rhoads BL, Langendoen EJ, Best JL, Ursic ME, Abad JD, Garcia MH. Spatial variability in bank resistance to erosion on a large meandering, mixed bedrock-alluvial river. Geomorphology. 2016;252:80-97.

[9] Schanz SA, Montgomery DR. Lithologic controls on valley width and strath terrace formation. Geomorphology. 2016;258:58-68. doi: 10.1016/j.geomorph.2016.01.015.

[10] Tooth S, McCarthy TS, Brandt D, Hancox PJ, Morris R. Geological controls on the formation of alluvial meanders and floodplain wetlands: The example of the Klip river, eastern free state, South Africa. Earth Surf Process Landf. 2002;27:797-815.

[11] Keller EA, Bean G, Best D. Fluvial geomorphology of a boulderbed, debris-flow - dominated channel in an active tectonic environment. Geomorphology. 2015;243(2015):14-26. doi: 10.1016/j.geomorph.2015.04.012.
[12] Falkowski T. Diversification of conditions and interflow volumes in morphogenetic sections of valleys within the lowland on the example of Toczna river. Ann Wars Univ Life Sci SGGW Land Reclam. 1997;28:31-9.

[13] Mycielska-Dowgiatło E. Rozwój rzeźby fluwialnej północno - zachodniej części Kotliny Sandomierskiej w świetle badań sedymentologicznych. Warszawa: Rozprawy Uniwersytetu Warszawskiego; 1978 (in Polish).

[14] Savichev OG, Reshetko M, Moiseeva YA. Methods of reconstruction of a zonal runoff in western Siberia in holocene. Bull Tomsk Polytech Univ Geo Assets Eng. 2016;327(5):87-96.

[15] Davis WM. The geographical cycle. Geogr J. 1899;14:481-504.

[16] Falkowski T. Związek poligenezy dolin rzecznych na Niżu z warunkami lokalizacji poddennych, infiltracyjnych ujęć wody. In: Górski J, Liszkowska E, editors. Współczesne Problemy Hydrogeologii, tom VIII, Poznań; 1997. p. 279-81.

[17] Falkowski T. The importance of recognition of polygeny for the rational utilisation of river valleys in Polish Lowland.

Proceedings of International Symposium Engineering Geology and the Environment. Rotterdam, Netherlands: A.A. Balkema; 1997. p. 107-11.

[18] Sieczka A, Bujakowski F, Koda E. Modelling groundwater flow and nitrate transport: A case study of an area used for precision agriculture in the middle part of the Vistula River valley, Poland. Geologos. 2018;24(3):225-35.

[19] Falkowski T, Ostrowski P, Siwicki P, Brach M. Channel morphology changes and their relationship to valley bottom geology and human interventions: A case study from the Vistula Valley in Warsaw, Poland. Geomorphology. 2017;297:100-11.

[20] Laszewski M. Wpływ niewielkich zbiorników na temperaturę wody rzek nizinnych na przykładzie Jeziorki i Rządzy. Przegląd Naukowy Inżynieria i Kształtowanie Środowiska. 2015;24:1-67.

[21] Marks L, Karabanov A, Nitychoruk J, Bahdasarau M, Krzywicki T, Majecka A, et al. Revised limit of the Saalian ice sheet in central Europe. Quaternary Int. 2018;478:59-74. doi: 10.1016/j.quaint.2016.07.043.

[22] Piotrowska K, Kamiński M. Szczegółowa mapa geologiczna Polski w skali 1:50000, arkusz Mińsk Mazowiecki (526). Warszawa: Państwowy Instytut Geologiczny; 2001.

[23] Kucharska M, Kamiński M. Glacitektonika w rejonie Dobrego na Wysoczyźnie. Przegląd Geologiczny. 2002;50(8):684-6.

[24] Nowak J. Szczegółowa mapa geologiczna Polski w skali 1:50000, arkusz Tłuszcz (489). Warszawa: Państwowy Instytut Geologiczny; 1981.

[25] Wierzbicki G, Ostrowski P, Mazgajski M, Bujakowski F. Using VHR multispectral remote sensing and LIDAR data to determine the geomorphological effects of overbank flow on a floodplain (the Vistula River, Poland). Geomorphology. 2013;183:73-81.

[26] Wierzbicki G, Ostrowski P, Falkowski T, Mazgajski M. Geological setting control of flood dynamics in lowland rivers (Poland). Sci Total Environ. 2018;636:367-82.

[27] Łaszewski M. Rekonstrukcja dawnego biegu rzek na podstawie archiwalnych materiałów kartograficznych. Komunikaty Rybackie. 2017;3:17-19.

[28] Twidale CR. River patterns and their meaning. Earth-Sci Rev. 2004;67(3-4):159-218.

[29] Meshkova LV, Carling PA. The geomorphological characteristics of the Mekong River in northern Cambodia: A mixed 
bedrock-alluvial multi-channel network. Geomorphology. 2012;147:2-17.

[30] Heitmuller FT, Hudson PF, Asquith WH. Lithologic and hydrologic controls of mixed alluvial-bedrock channels in floodprone fluvial systems: Bankfull and macrochannels in the Llano River watershed, central Texas, USA. Geomorphology. 2015 Mar 1;232:1-9.

[31] Darby SE, Alabyan AM, Van, de Wiel MJ. Numerical simulation of bank erosion and channel migration in meandering rivers. Water Resour Res. 2002 Sep;38(9):2-1-2-21.

[32] Alfieri L, Feyen L, Dottori F, Bianchi A. Ensemble flood risk assessment in Europe under high end climate scenarios. Glob Environ Change. 2015;35:199-212.

[33] Schumm SA. Fluvial geomorphology: Channel adjustment and river metamorphosis. River Mech. Fort Collins: Water Resour; 1971.

[34] Mojski JE. Area of Poland in quaternary an outline of morphogenesis. Warszawa: PIG; 2005.

[35] Falkowska E. Glacial morphogenesis of uplands of the Warta Glaciation in Poland as a control on heavy metal distribution in deposits. Geol Q. 2009;53(3):293-304.

[36] Różycki SZ. Plejstocen Polski Środkowej na tle przeszłości w górnym trzeciorzędzie. Naukowe: Państwowe Wydawn; 1972.

[37] Aber JS, Ber A. Glaciotectonism. Amsterdam: Elsevier; 2007.

[38] Bujakowski F, Falkowski T, Wierzbicki G, Zukowska K. Using hydrodynamic modelling to assess the impact of the evelop- ment on hydrogeological conditions in a polygenic river valley marginal zone. Ann Wars Univ Life Sciences-SGGW Land Reclam. 2014;46(1):43-55.

[39] Rabarijoely S, Bilski P, Falkowski T. Usage of the graph clustering algorithm to the recognition of geotechnical layers. Ann Wars Univ Life Sci SGGW Land Reclam. 2007;38:57-67.

[40] Schanzer EV. Alljuvy of the flat rivers of a moderate zone and its value for knowledge of laws of a structure and formation of alluvial retinues/Works of Institute of geological sciences, Number 135. A Geol Ser (No 55). Publishing house of the Academy of sciences of the USSR [in Russian]; 1951.

[41] Blöschl G, Hall J, Parajka J, Perdigão RA, Merz B, Arheimer B, et al. Changing climate shifts timing of European floods. Science. 2017;357(6351):588-90.

[42] Falkowski T, Ostrowski P. Morfogeneza powierzchni tarasu zalewowego Wisły w okolicach Magnuszewa w obrazie zdjęć satelitarnych i lotniczych. Infrastrukt i Ekologia Terenów Wiejskich. 2010;9:89-100.

[43] Fryirs K, Brierley G. Practical applications of the river styles framework as a tool for catchment-wide river management: A case study from bega catchment. NSW, Australia, Auckland: Macquirie University; 2005. p. 227.

[44] Bujakowski F, Falkowski T. Hydrogeological analysis supported by remote sensing methods as a tool for assessing the safety of embankments (case study from Vistula river valley, Poland). Water. 2019;11(2):266. 